By CHARLES B. SHAW

\title{
Further Lists of Books for College Libraries
}

\section{Charles B. Shaw is librarian at Swarth- more College.}

ACTION TOWARD the provision of further published lists of books for college libraries points first toward another, but smaller, supplementary volume covering two or three years. The original volume and the existing supplement include statements of the appropriate books published through 1938. Another similar compilation to catch up arrears and to provide for a future period (a period sufficient to work out plans and procedures for a yet-to-be-initiated series of more frequent supplements) might well be a three-year inclusion covering the years 1939, 1940, and 194I. It might be possible to reduce this to a two-year volume for 1939 and 1940 , but the processes of assembling twenty-four advisory groups of faculty experts; the work of checking, rechecking, and checking again several hundred titles; the mechanics of typing; correspondence; the final digesting of recommendations and the selecting of titles; the preparation of printer's copy; proofreading; index-making-all these obligations combine in such a complicated and time-consuming task that, with 1940 already having passed, it would seem far wiser not to attempt the two-year volume. It would be expedient, however, in the near future to evolve a program which will assure editorial activity during the last quarter of I94I and the first quarter of 1942, with the consequent completion of a three-year I939-I94I supplement during the spring of 1942 .

I have not attempted to prepare an itemized budget of editorial and production costs for such a publication. The A.L.A. cannot quote a definite selling price on a book for which the manuscript does not exist. For each of the two previous publications there has been a subsidy consisting of a grant from the Carnegie Corporation of New York. If some similar subsidy is again made available and the book materializes in the proportionate size that experience with its predecessors indicates it might (probably I300-I 500 titles), the chief of the publishing department of the A.L.A. estimates that a three-year supplement could be priced at $\$ 4$ to $\$ 4.25$ if there is assured a sale of at least one thousand copies.

Beyond this proposed three-year supplement there are two divergent ways of procedure.

One is the production of a series of annual volumes, similar in every respect but size, to the books al ready issued. Each annual volume would be prepared as its predecessors have been, in the light of advice from many experts, and would express a carefully considered appraisal by the admission of any title to the list. The preparation of such a compilation could probably be completed during the spring 
of the following year: i.e., the 1942 volume could be made ready for publication before the start of the summer vacation of 1943. Here again the problem of a subsidy has to be faced. If a foundation is unwilling to grant a continuing series of small subventions some institution may be persuaded (as certain universities now subsidize some learned journals) to assume editorial and other pre-manufacturing costs. Again with the caution that the figure is no more than a rough estimate, the chief of the A.L.A. publishing department suggests that an annual supplement, listing from 400 to 500 titles, would be priced at $\$ 2.25$ or $\$ 2.50$ if there is an assured sale of 700 copies.

\section{Quarterly List}

The other suggested way of procedure is the issuance of a quarterly list of titles suitable for college and university library purchase. The A.L.A. estimate of cost for the quarterly issuance of such a list (a pamphlet that might approximate in size the Subscription Books Bulletin) is about $\$ 3$ a year if there are from 1200 to I 500 subscribers, or from $\$ 3.50$ to $\$ 4$ a year if there are only from 700 to 1000 subscribers. A correlative suggestion is the inclusion of such a listing of new titles as a regular department of College and Research Libraries. This quarterly publication assures the possibility of prompt acquisition (a January, I 942 publication could presumably be included in the March, 1942 quarterly listing) but it gains this promptness perhaps by sacrificing what may be the far more valuable asset of authoritativeness.

The list which has the virtue of timeliness must be assembled largely on the basis of reviews in such lay or popular media as the New York Times book re- view section, Books, the Nation and the New Republic rather than on the specialized reviews of experts that appear in each subject's learned journals. A fragmentary but time-consuming check of this aspect of book-evaluation yielded the following pertinent bits of information. The findings, of course, have no final significance, but they are indicative of the discrepancies in the availability of estimates of new publications that are inherent in the two contrasting conceptions of promptness and authority. This check is on the lapses of time between the date of publication of a book (as shown by its entry in the Publishers' Weekly, the date of its review in one of the popular weekly media and the date of the availability of its review in a standard scholarly journal (as indicated by the date of the arrival of an issue at our library). For this check the reviews of twenty haphazardly selected titles in five fields of knowledge have thus been examined. In these twenty instances the average interval between the date of a book's appearance and its review in one of the popular media is 15 days. The average interval between the date of the book's appearance and the availability of its authoritative review in its own specialized journal is 60 weeks. There is a lag here of a little more than a year. It is during this year that the book is being examined and used by competent subject specialists-by those individuals whose opinions will have determining weight in the admission or rejection of these titles in an annual volume.

Different Aims of Aids

A second check is on an analogous situation in other of our professional book (Continued on page 189) 
Agnes M. Johnson, Columbia '33, formerly at Kern County Library, has been appointed bibliographer.

Mrs. Lisl Loeb, California '4o, is now assistant in the catalog department.

Anna F. Pitney, California ' 40 , is an assistant in the accessions department.

Mrs. Alice F. Reynolds, Columbia '38, is an assistant cataloger for the Bancroft Library.

Dr. Diether von den Steinen has been appointed curator of the Chinese and
Japanese language collection. Dr. von den Steinen spent eleven years in China.

Ruth L. Steinmetz, assistant chief of the bibliography division, has been assigned to the School of Education Library.

Robert Vosper, California '40, is assistant in the reference division.

Jerome K. Wilcox was promoted from assistant librarian to associate librarian July I, I940.

Gordon Wilson, California '40, is now assistant in the catalog department.

\section{Further Lists of Books for College Libraries}

\section{(Continued from page II 8 )}

selection aids. The Booklist aims at the prompt evaluation of books considered suitable for immediate library acquisition; the A.L.A. Catalog is an expression of the deferred judgment on such titles as basic books. Again, this sampling is not infallibly conclusive, but it is further indicative of those discrepancies in book selection aids. In this check Ioo haphazardly selected titles from the Booklist were checked against the A.L.A. Catalog, 19321936. Of the roo Booklist-cited titles only 37 were included in the later publication. In this random sampling, therefore, 63 per cent of the immediately accepted titles were rejected in the later compilation of books desirable for permanent library acquisition. It seems reasonable to suppose that a similar variation might be expected among those titles recommended in corresponding current and basic lists aimed at college book selection.

One still further possibility, if support should warrant it, would be the adoption of both procedures: a quickly prepared quarterly list (like the Booklist).
Twenty issues of this would become the basis, not of cumulation, but for the compilation of a revised authoritative and tested selection (like the A.L.A. Cata$\log$ ) to be issued as the next inclusive five-year volume in a series including the original book, the existing I93 I-I938 supplement, and the proposed I939-I94I selections.

All these proposals are unofficial, tentative, and suggestive. So far as I know, no scheme of procedure has been adopted or even planned in detail by any organization. Before there is a commitment to any plan I believe that there should be some canvassing of the opinions of, and some investigation of the possibilities of participation by, official representatives of the various learned societies whose fields of interest are included in the publication. In addition to such extra-professional discussions I am sure that the publishing department of the A.L.A. and the officials of the Association of College and Reference Libraries will welcome your letters of comment and advice. 